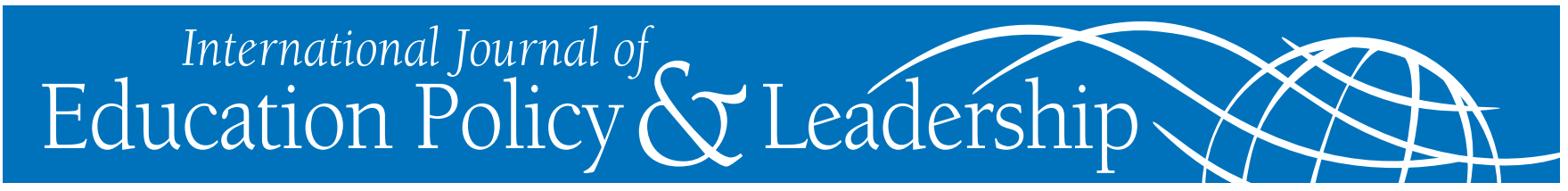

\title{
Policy in the Way of Practice: How Assessment Legislation Is Affecting Social Studies Curriculum and Instruction in Ohio
}

\author{
THOMAS Misco \\ Miami University \\ NANCY PATTERSON \\ Bowling Green State University \\ FRANS DOPPEN \\ Ohio University
}

\begin{abstract}
In a national context of standards and high-stakes testing, concerns are emerging about challenges to the already tenuous position of the citizenship mission in the social studies curriculum. In this qualitative study, the authors administered a survey to social studies teachers in Ohio and conducted follow-up interviews focusing on the present purposes of social studies and the ways in which standards and testing are affecting instructional practice. The findings reveal a perception of standards as being of high quality, yet ultimately undermined through changes in scope and sequence, narrowing of the curriculum, and a paucity of time to enact them. In addition, respondents indicated that high-stakes testing has become the primary curricular focus, which impacts instructional strategy decision making and frustrates citizenship education.
\end{abstract}

Misco, T., Patterson, N., \& Doppen, F. (2011). Policy in the Way of Practice: How Assessment Legislation Is Affecting Social Studies Curriculum and Instruction in Ohio. International Journal of Education Policy and Leadership 6(7).

Democratic societies require a high level of "social understanding and civic efficacy" (NCSS, 1994, p. 157) of its citizens, much of the responsibility for which lies with social studies teaching and learning. This guiding vision is derived from both the uniquely large and diverse range of content and the responsibility placed on teachers for addressing the ethical and social underpinnings of content topics. It calls for powerful teaching that engages students in a coherent citizenship education curriculum that includes the "difficult process of confronting ethical and value-based dilemmas, and encourages students to speculate, think critically, and make personal and civic decisions based on information from multiple perspectives" (NCSS, 1994, p. 159).

In light of this mission and vision, it is of concern to social studies educators that a growing num- ber of regional studies (Barton \& Levstik, 2004; Heafner, Lipscomb, \& Rock, 2006; Rock et al., 2006; VanFossen, 2005) suggest social studies education is frequently marginalized within the context of high-stakes testing legislation that often privileges reading, writing, math, and science. Moreover, by primarily focusing on these other disciplines and emphasizing content coverage and content knowledge that is easily measured through high-stakes tests, the work of citizenship education may be significantly affected. This case study of Ohio social studies teachers seeks to advance this line of research by exploring the nuanced interplay of social studies goals and pedagogy with standards and teaching. It explores the ways in which teachers are interpreting and enacting changes in their classroom in response to these pervasive policies. 


\section{Research Context}

Findings about the use of large-scale, state-level testing legislation as a lever to improve classroom teaching and student learning remain unsubstantiated and intensely contested (Grant \& Salinas, 2008, p. 227). In New York, Grant (2001) found that although teachers may differ in the way they give attention to the state test, it does not seem to drive teaching and learning and is "an uncertain lever at best" in changing teachers' practices (p. 421). Marker (2001) has argued that there is "no research evidence whatsoever" to indicate it enhances student performance (p. 359).

Researchers have explored some specific effects of such policies in the areas of content, pedagogy, and ideology. Grant and Salinas (2008) have suggested that although most observers agree that new state tests influence teachers' classroom practices, it is equally evident that these influences are not of a singular kind, and that while teachers make changes in the content they teach and the assessments they develop, changes in instructional practices are less evident. They posit that although recent research findings are mixed, it appears that few teachers are giving over their classrooms to lecture, recitation, and test preparation. In Michigan, however, Segall (2003) found that although the social studies state test was tied to monetary rewards for the school and not for individual students, teachers nonetheless thought it was important for their students to be successful and therefore compromised their values "as much on how [they taught] as on what they taught" (p. 319).

More recently, Yeager and van Hover (2006) found that two beginning social studies teachers in Florida and Virginia took it as a personal challenge to not let the state test drive the nature of their teaching. Although the absence of a social studies test in Florida led Suzanne to focus on teaching her students literacy skills that were directly tested on the state exam, in Virginia the end-of-year state tests led Claire to cover the required curriculum for the courses she taught "at a brisk pace" (p. 354), as she would be personally held accountable for her students' test scores. In New York, Gerwin and Visone (2006) found that teacher instructional strategies differed in classrooms with tested and non-tested history courses, as teachers enjoyed the freedom to diversify strategies in elective classes, thus indirectly reporting constraints imposed on teaching by the presence of high-stakes tests.

Teachers who spend the most time on test preparation are more likely to use teacher-centered practices, including multiple-choice questions, textbooks, lecturing, and textbook-driven work (Vogler, 2005). Within these classrooms, students often engage in the practice of "collecting bits of low cognitive-level information in the most time-efficient way with little mention of or regard for how this information fits into the bigger picture" (Vogler \& Virtue, 2007, p. 54). Some states, including Ohio, are also moving beyond simply filtering regular content for test preparation and entering the dangerous terrain of tests serving as the actual content. This phenomenon is compounded by the degree of high-stakesness, whereby more instructional time is devoted to test preparation (Firestone, Schorr, \& Monfils, 2004; Vogler $\&$ Virtue, 2007; Vogler, 2005). In these situations, students are not taught to be lifelong learners, but are drilled and "taught how to find test clues," a skill which has little transferability outside of the school (Wright, 2009, p. 119).

Recently, we piloted a survey among Ohio social studies teachers (Doppen, Misco, \& Patterson, 2008) and found that they often make the assumption that increased assessment requires rote or low-level learning and the acquisition of declarative knowledge. The pilot study suggested that the current combination of standards and testing has a significant effect on social studies teaching and learning and drives changes in content and pedagogy. The pilot also found that the presence of state testing has had an influence on teacher decisions concerning the degree to which powerful teaching is a focus in social studies classrooms, including pedagogy that is active, meaningful, value-based, and challenging (NCSS, 1994). In this study, we focus on the effect highstakes testing may have on content and pedagogy, and suggest that in Ohio in particular, the lever of testing may indeed be moving teachers toward teaching that does not align with the original citizenship education intent of the standards.

\section{The Study}

We chose to conduct a qualitative case study given the dynamic nature of the research problem and the interpretivist research questions (Miles $\&$ Huberman, 
1994; LeCompte \& Schensul, 1999). Because case studies are extremely useful for understanding a particular and unique problem in an in-depth way, we decided to view Ohio social studies teachers as a case. Although each teacher is unique, the peculiarities of each state's standards and testing requirements unfold in distinct ways, thereby creating 50 cases and cases within those cases. Qualitative case study inquiry is about what people do and why they do it and, as social agents, outsiders are well-positioned to learn about a culture or subculture because they enjoy the etic perspective allowing for the discernment of and access to meaning.

\section{Context}

Social studies education is well-defined in Ohio standards and assessment, but little is known about the ways in which social studies teachers align practice with the Ohio Academic Content Standards (OACS) for social studies and the effect of Ohio's state test legislation and policies on instructional practice. Social studies has been part of the 10th grade Ohio Graduation Test (OGT) since its third administration in March 2005. Ohio also implemented an Ohio Achievement Test (OAT) (although it was suspended in 2009 due to state budget shortfalls), specifically for social studies in the 5th and 8th grade, in May 2007. These innovations are the first steps in an overall state assessment system that will ultimately include a standardized social studies scope and sequence from pre $\mathrm{K}-12$ with benchmark tests and a graduation test. ${ }^{1}$

In this study, we sought to understand effects of the overall policy through examining the interaction of content standards within the context of increased testing. Understanding this interplay is integral to the preparation of future teachers and the professional development of practicing teachers as they attempt to respond to the citizenship-oriented purposes of social studies while simultaneously ensuring student

${ }^{1}$ During its 2009 session the Ohio Assembly passed H.B. 1 and suspended the OAT for Social Studies for two years. Although the Ohio Department of Education at the time was adamant that legislators would reinstate the OAT, its suspension has been continued through at least the 2012-13 academic year. mastery of prescribed content. Our research questions included:

- What is the influence of the Ohio assessment legislation (standards and testing) on teacher curricular decision-making?

- To what extent do these decisions advance or undermine the identified purposes of the standards?

\section{Methodology}

\section{Data Collection}

Our experience with the pilot study left numerous questions that required clarification. We therefore readministered the survey and strengthened it with interview data to disentangle the nuanced influence of standards and testing on curriculum and instruction. We randomly selected and administered the survey to 1,000 respondents from a database of secondary teachers in Ohio (500 of the 4,937 middle/junior high teachers and 500 of the 6,243 high school teachers). The overall response rate was 23 percent.

We originally developed the survey based on an instrument designed for a state study of $\mathrm{K}-5$ teachers in Indiana (VanFossen, 2005). We developed a multiple-page online survey with an invitation sent through postal mail. To maximize the response rate, we used various techniques that have been known to increase response rates. First, the structure of the survey employed the strategy of preliminary notification (Yammarino, Skinner, \& Childers, 1991; Cole, Palmer, \& Schwanz 1997; Dillman, 1991; Fox, Crask. \& Kim, 1988), which has shown to increase responses from as low as 8 percent (Fox et al., 1988) to as high as 29 percent (Yammarino et al., 1992).

Second, we offered a small monetary incentive, as there is a strong positive correlation between small incentives and increased response rates (Yammarino et al., 1991; Cole et al., 1997; Dillman, 1991; Fox et al., 1988). Therefore, for the current version of the survey, we offered numerous moderately priced incentives (ten $\$ 30$ gas cards) to those who would complete the survey (Fox et al., 1988). We sent reminder e-mails to the respondents, as this has often been found to be an effective way to increase response rates (Cole et al., 1997). Finally, we also used less effective but still statistically significant strategies, 
including university sponsorship (Fox et al., 1988) and a relatively short and easy-to-follow survey format (Cole et al., 1997). The final phase of data collection involved individual interviews with survey respondents to explore more deeply the meaning these teachers make of standards, the state test, and social studies in practice (Patton, 1990). We designed the structured interview questions to fit within the research questions, provide illumination for the study, be anchored in the reality of the respondents, and draw from their lives (Glesne, 1999).

Our purposeful sampling strategy (Patton, 1990) identified teachers in a wide variety of settings and with differing conceptions of citizenship education. The effects of standards and testing on social studies teaching require attention, but these are certainly not the only variables at work. The literature related to the effect of teacher beliefs on change has relevance for this study, in that beliefs have been shown to be strong predictors of behavior (Pajares, 1992), and as such, we took advantage of teacher beliefs about citizenship to guide our sampling.

In our previous study of teacher beliefs about the purposes of social studies, we found that teacher beliefs about the citizenship mission of social studies may affect their decisions about instructional focus. In that study, we categorized teacher orientations based on the continuum established by Westheimer and Kahne (2004) that describes teachers as Personally Responsible, Participatory, or Justice-Oriented and linked these orientations to certain types of classroom practice. The Personally Responsible construct includes the attributes of being moral, honest, respectful, hard-working, self-sacrificial, lawabiding, proud of one's community, and patriotic. The Participatory construct includes attention to issues in the local community and beyond. It values knowledge not only to communicate to students what they know, but also to help them gain a broader understanding of perspectives uncommon to them. Knowledge is more theoretical, with a concern for student awareness of diversity and inequity in the larger society. The Justice-Oriented construct includes a distinct commitment to calling students to action, whether through letter writing, petitioning, or protesting on matters of the common good. This construct values and uses knowledge in service of problem-solving community and global issues.
To select interviewees, we identified three regions of the state that corresponded to our respective locations and purposefully selected a balance of teachers across the citizenship continuum. We also selected teachers across the secondary licensure bands (grade 6-12). Our rationale for doing so was that middle (grade 6-8) and high (grade 9-12) school teachers at these grade levels typically teach in their content area only. Based on survey and interview responses to the question of what defines a "good citizen," we identified 12 teachers throughout the state, four in each of the three orientations. Of the number invited to participate in the interview process, nine responded favorably. The interviews were conducted at the interviewees' convenience (Hammersley \& Atkinson, 1995), some in person and some by telephone (Table 1).

\begin{tabular}{cc}
\hline $\begin{array}{l}\text { Table 1: Interview } \\
\text { gorization }\end{array}$ \\
\hline Pseudonym & Citizenship Categorization \\
Barry & Personally Responsible \\
Melissa & Personally Responsible \\
Marcus & Personally Responsible \\
Elsie & Personally Responsible \\
Cindy & Participatory \\
Robin & Participatory \\
Dora & Justice-Oriented \\
Brandon & Justice-Oriented \\
Karen & Justice-Oriented
\end{tabular}

Four of the participants who agreed to participate in the interviews were ultimately categorized as Personally Responsible (Barry, Melissa, Marcus, Elsie), two as Participatory (Cindy and Robin), and three as Justice-Oriented (Dora, Brandon, and Karen). Barry was a Caucasian male in his second year in the classroom teaching 9th grade World History and U.S. Government. Marcus was a Caucasian male who had taught for 10 years in the local community in which he grew up. He taught 8th grade American History. Elsie was a Caucasian female who was a 6th grade teacher. She was a stay-at-home mom for 18 years and began teaching 5 years ago. Cindy, a high school teacher, and Robin, who taught in a middle school, were both Caucasian females with 10 and 15 years of experience respectively. Dora was a Caucasian female who had taught 8th 
grade social studies for 15 years. Brandon was a Caucasian male who had taught 8 th grade social studies for 10 years. Karen was a Caucasian female who had taught 9 th grade social studies for 5 years.

\section{Data Analysis}

Rather than apply analytical tools a priori, we drew from the suggestions of numerous qualitative methodologists, as well as the data, to inform an emergent approach. Although analysis often draws on the researcher's past experiences (LeCompte \& Schensul, 1999a), we intentionally set out to make the comparisons, category constructions, and interpretations explicit and grounded in the best available analytical techniques appropriate for this study.

We reduced data into manageable forms that allowed for interpretations through a process of dissecting, dividing, and reassembling data into understandable forms (LeCompte \& Schensul, 1999b), first collecting and summarizing all survey data, both in numerical and narrative forms. For purposes of credibility and accuracy, we reached and cut across multiple data sources (Merriam, 2001; Miles \& Huberman, 1994), using the interview data to clarify survey findings and creating cases for each individual that included both survey and interview data. We then separately read through each case independently to develop and identify themes related to the research questions (Doppen, Misco, \& Patterson, 2008; Westheimer \& Kahne, 2004) Next, we compared our separate analyses to solidify common themes within and between cases. Finally, we reread the cases and coded for instances that would exemplify and define each theme (Glasser \& Strauss, 1967).

\section{Findings}

The analysis revealed that teachers' responses to the Ohio assessment system are both positive and negative. The two comprehensive findings that emerged were the neutral to beneficial effects of the standards and the negative effects of the high-stakes tests. Our findings are organized around the first research question about the effects of the Ohio assessment system (standards and testing) on teacher curricular decision-making. We begin with teachers' baseline approach to social studies serving as the foundation, followed by a discussion of the perceived effects of Ohio's evaluation system in terms of the standards as well as testing. The second research question, regarding the extent to which these decisions advance or undermine the identified purposes of the standards, is addressed in the conclusion.

Each section of the findings includes an integrated description of survey and interview data, with a discussion of how data sources compare and thereby enrich our inquiry. The baseline data of teachers' approaches to social studies is followed by a description of reports on how standards affect their curricular decision-making. Themes that emerged from this analysis as affecting planning include scope and sequence concerns and time constraints. We then address teacher reactions to the high-stakes test, including struggles with testing as the primary curricular focus and resulting changes in instructional strategies.

Two questions from the survey provided us with some background about teachers' approaches to the subject they teach, one that asked them to rank some reasons for teaching social studies and one that asked them to rank it in importance to other subjects. This sample of secondary teachers values social studies highly in relation to the other content areas (Table 2) and acknowledges the importance of the citizenship mission of the field.

Table 2: Importance of Content/Subject Areas

\begin{tabular}{lcc}
\hline $\begin{array}{l}\text { Content/Subject Area } \\
{[n=181]}\end{array}$ & $\begin{array}{c}\text { Weighted } \\
\text { Rank }\end{array}$ & $\begin{array}{c}\text { Absolute } \\
\text { Rank }\end{array}$ \\
$\begin{array}{lc}\text { Reading/Language Arts } \\
\text { Mathematics }\end{array}$ & 1.61 & 2 \\
Social Studies & 3.00 & 3 \\
Science & 3.47 & 4 \\
$\begin{array}{l}\text { Health/Physical Educa- } \\
\text { tion }\end{array}$ & 4.71 & 5 \\
Art/Music & 4.98 & 6 \\
\hline
\end{tabular}

The highest ranked reasons for teaching social studies were appreciation and awareness of community, nation, and world; and the preparation of future 
citizens. Conversely, meeting the requirement of state standards, preparing students for the next grade level, and teaching reading skills all figured as the least important reasons for teaching social studies (Table 3).

Table 3: Ranked reasons for teaching social studies

\begin{tabular}{lcc}
\hline \multirow{2}{*}{ Reason } & \multicolumn{2}{c}{ Total (n = 181) } \\
\cline { 2 - 3 } $\begin{array}{l}\text { To teach students an apprecia- } \\
\text { tion and awareness of their }\end{array}$ & 1.86 & 1 \\
community, nation, and the & & \\
world. & & \\
To prepare good citizens. & 2.42 & 2 \\
$\begin{array}{l}\text { To teach students content } \\
\text { knowledge. }\end{array}$ & 3.10 & 3 \\
$\begin{array}{l}\text { To teach students life skills. } \\
\text { To develop skills in language }\end{array}$ & 3.13 & 4 \\
arts and reading. & 4.26 & 5 \\
$\begin{array}{l}\text { To prepare students for the next } \\
\text { grade level. }\end{array}$ & 4.80 & 6 \\
$\begin{array}{l}\text { Because it is required by state } \\
\text { standards. }\end{array}$ & 5.20 & 7 \\
\hline
\end{tabular}

\section{Effects of the standards on teacher curricu- lar decision-making}

In this section, we present teachers' self-reported reactions to the Ohio Academic Content Standards and testing. In general, teacher responses to the standards were positive. The survey data suggest that nine out of 10 respondents either always or occasionally implemented the OACS (Table 4).

The commonplace familiarity with an implementation of the standards was evident from the survey, but the interviews clarified what teachers meant by "implementing" content standards. Issues related to scope and sequence, allegiance to citizenship aims, and time collectively speak to the changes in curriculum and instruction when the content standards are met.
Scope and sequence

One emergent theme on the issue of aligning practice to content standards was the tendency for teachers, even if critical, to praise the standards as an important tool for focusing the curriculum. Melissa indicated that she uses the standards as a timeline and then "take[s] the other standards and ... put[s] them in" and Dora stated their value was in their ability to help her focus the curriculum. Barry voiced no complaints, as he thought the standards are thorough and enable teachers to retain autonomy. In particular, he recalled using textbooks, supplements, and the standards to bring about innovative and engaging lessons. He complimented the authors of the standards for developing goals that are "specific enough without being so rigid. They basically give you the topics. What you do with those topics, you have autonomy and I think they've done a really good job of choosing those that are important." By using the standards as "the ultimate guideline" while retaining curricular autonomy, many teachers in Ohio are wellpositioned to meet the intent of the Ohio Department of Education.

Table 4: Implementing the OACS in Instructional Planning

\begin{tabular}{|c|c|c|}
\hline & Total & \\
\hline Frequency & $\mathrm{N}$ & $\%$ \\
\hline Almost always & 151 & 74.1 \\
\hline Occasionally & 40 & 19.6 \\
\hline Rarely & 7 & 3.4 \\
\hline Almost Never & 6 & 2.9 \\
\hline Total & 204 & 100.0 \\
\hline
\end{tabular}

Generally, teachers were supportive of the standards, and most agreed that they teach to the standards every day. Criticism was limited to suggestions about scope and the time in which voluminous content was expected to be covered. Melissa stated, "I would like to delete some and add some. Otherwise I'm fine with the way they suggest and direct units." Dora argued that the 8th grade test covers too much and sets the students up for failure, and Cindy said, "I 
tend to feel oppressed by them. I look at them at the beginning of the year and think these are things I know how to deal with-things I will get to-but then everything gets crazy and by the middle of the year, this is hopeless."

Dora was one teacher who was a bit more scathing in her criticism, mainly due to the connection of the standards to testing, an issue we bring up in more depth later. She "felt so bad for the kids but yet, there was so much pressure that that's what we need to do. You need to pass this test. Oh, we didn't pass last year and we have to improve and it's very, very frustrating." In short, the interview data suggest that teachers generally support the standards and do so primarily because of their specificity, breadth, and flexibility.

\section{Time}

The other theme that arose through data analysis concerned the nature of instructional time associated with meeting the content standards. Melissa complained that, "there is not the time to get through the history I want." Social studies teachers have long felt a lack of time, even long before the advent of content standards. For example, Cindy teacher argued, "the idea of an NGO ... would take like six months," but is exacerbated by her "nervousness of looking at the Ohio standards and saying 'there's a lot of content'." If there are "only 180 days" and "lots of things to check off," "how do you try to give a little bit of meat to some things and not make it simply Jeopardy style/Quiz Bowl knowledge?" Barry, while seemingly unaffected by and generally accepting of the standards, did state, "I purposefully, in my World History course, I zip through the 20th century so I can get to what is affecting these kids today." Widespread implementation of and support for the standards is thus tempered by concerns about scope and sequence and time.

\section{Effects of the test on teacher curricular deci- sion-making}

Our findings suggest there is a profound impact of the test on social studies teachers, including a shift to testing as the primary curricular focus of content decision-making and significant changes in instructional strategies. The frustrations many teachers al- ready felt is further compounded by the tests. Even if the standards seem reasonable in theory, when they are applied in conjunction with an achievement test, the following scenario from Marcus' classroom easily plays out:

See, in 8th grade I'm responsible for what was taught in 6 th and 7 th grade, which was [World Cultures and] World History. So I've got to re-teach, or review that and then I've got to teach from Columbus, 1492 to 1865 , a little after 1865, 1870 through Reconstruction, 1492 to 1877 . So that's 400 years of history that I've got to teach, plus I've got to cover world history back to the dawn of civilization and the Tigris and Euphrates river valley, China, the Huang He, you know, the river valley. So it's just an awful lot of stuff to cover, but the 8th grade Academic Content Standards are reasonable, if I didn't also have to worry about 6 th and 7 th being measured by the achievement test.

Testing as the primary curricular focus

The ultimate effect of these forces on the instructional and curricular authority of the teacher results in surface coverage of a wide variety of topics. Moreover, the bulk of this content is disconnected from students' lives and undermines the efforts of creative generative teachers to attend to their students' interests. In short, although the standards are typically viewed positively by teachers sui generis, when they are located in relation to total number of the standards to be taught, high-stakes state tests, limited instructional time, and decreased curricular autonomy, they have a largely negative educational effect.

Dora found herself apologizing to her students throughout the year, typically when teaching would be overtaken by test preparation. She recalled saying:

'I'm really sorry that we have to review again.' I like to do simulations, I like to do debates and all the things like that and when you get, especially in the six weeks or so before the test, you just can't, because it's so much, so much pressure. And I think a big part of it is the way Ohio funds its schools because if we didn't have to worry about public opinion, 
passing the levies ... I mean, how can you teach kids citizenship skills when you don't have time to converse in class?

This disturbing consequence led Karen to "not really look at [the standards]. I guess four times a year, I have to design lesson plans, and then I look at the content standards."

The OGT has come to completely dominate curriculum planning for many teachers. In some cases, such as Robin's, it is a badge of pride. She commented:

"We are aligned with OGT; I am on the state social studies content committee; I feel 95\% of what they have on there are the things I try to get across to my students anyhow; I see those as key points; so we are aligned with OGT. Even if I teach outside of the standards, some of those standards just come in anyhow."

She offered a Panglossian vision of "teaching multiple strands at the same time" but still noted that "you only have ten months of the year and you can't get through everything." Barry felt the tests are "a good thing" and that these standards are not very high. "You can pass the OGT with a 45." For Robin, initially the standards were not a problem to implement because they were something she valued and agreed with. It became progressively more concerning to her to be able to cover all the content and preserve the "teachable moments" she used to have before the high-stakes tests came into being.

Brandon's school experienced a "dismal performance last year" and as a result, as a curricular focus, it is "really having such a huge impact on everything now." Respondents in other schools noted that "most are successful on the OGT if you just say, 'you need to graduate'. If you say, 'you need to know this and that,' they will say 'I don't care.' If you really push it, you really need this to graduate, this makes our school look really good, then they are successful." By "really pushing it on a daily basis," the end result is that "the OGT is the focus in every class."

\section{Changing instructional strategies}

Interviews with survey respondents revealed nuanced ways in which the content standards influence decision-making about instructional strategies. The bulk of respondents indicated that prior to the adoption of the standards, or as beginning teachers imagining the classroom without standards and testing, they would employ a wide variety of strategies to not only foster student engagement but also respond to diverse learning styles. Writ large, social studies teachers in Ohio view discussion, inquiry-based projects, and simulations to be the most effective strategies (Table 4).

The presence of the test appears to have altered the way teachers make decisions about the curriculum. The majority of teachers agreed or strongly agreed that the test had an effect on their teaching. The perceived need to cover basic content is seen statewide, but at a cost: namely, the perceived schism of citizenship skills and the test (Table 5). Significantly, when we juxtapose the most important characteristics for OAT/OGT preparation with learning social studies were there no test, citizenship skills and critical thinking gain higher priority (Table 6 , page 9 ).

\begin{tabular}{lcc}
\hline $\begin{array}{l}\text { Table 5: Most Important Characteristics in Pre- } \\
\text { paring Students for the OAT/OGT }\end{array}$ \\
\hline & \multicolumn{2}{c}{ Totals } \\
\cline { 2 - 3 } & Level & Rank \\
\hline Basic content knowledge & 2.03 & 1 \\
Critical thinking skills & 2.11 & 2 \\
Writing skills & 3.10 & 3 \\
Test taking skills & 3.18 & 4 \\
Citizenship skills & 3.75 & 5 \\
\hline
\end{tabular}

In the interviews, we asked teachers to clarify how the test has affected their teaching. A number of participants discussed how their classrooms and the school environment have changed in this context. In some cases, direct instruction and lecturing have become much more prominent. Melissa offered the following perspective:

I do a lot more lecturing than I would like to. If there were no standards, we would do a lot more, or if I cut half of them out, we could 
do a lot more projects. I could spend a week on it (Holocaust); now we spend two days. Lecture is the most prominent strategy I use, with PowerPoint.

\begin{tabular}{lcc}
\hline $\begin{array}{l}\text { Table 6: Most Important Skills for Learning Social } \\
\text { Studies if no OAT/OGT }\end{array}$ & & \\
\hline Content Area & Level & Rank \\
Critical thinking skills & 1.95 & 1 \\
Basic content knowledge & 2.09 & 2 \\
Citizenship skills & 2.74 & 3 \\
Writing skills & 3.19 & 4 \\
Test taking skills & 4.24 & 5 \\
\hline
\end{tabular}

Note: Most effective [1] to least effective [5].

Although she stated she tries to do group activities as much as she can, it often comes in the form of "working on a worksheet together and going over it as a group." On occasion she is able to employ a "take a stand" strategy with plenary discussion, but, more often than not, engaging strategies are left to elective classes, such as Psychology. Melissa described the difference for her teaching a non-tested curriculum: "That changes significantly for the psychology class; gosh, I have tons more freedom; not having the standards you can tell a big difference. I spend four weeks doing an experiment on classical and operant conditioning. I have much more fun teaching those classes."

Marcus has had to revert to what he considers to be the most efficient strategy in a testing contextlecture. He stated, "I can cover more ground with lecture and notes, but in my opinion not be as effective as I would be by allowing students to create simulations, group projects, multimedia presentations, etc." This is just the continuation of the breadth-not-depth concept. Marcus stated, "You're going to see direct instruction, lecture, things of that nature," and other strategies that are closely associated with test preparation, including diagramming, worksheets, and note taking.

It appears that curricular decision-making increasingly is based primarily on standards and test- ing, leaving students, teachers, and the subject matter increasingly marginalized. The ultimate effect of this shift in instructional decision-making led Dora to question her worth as a professional. She stated, "I feel like a bad teacher because we are just drilling, drilling, drilling. Make sure you remember this, and what about this, and we were going through these review books we ordered and, you know, it was just work." Before the presence of the high-stakes test, her students did more inquiry-based work. They used to "evaluate sources and that sort of thing" but with the test in place, Dora reports not having the time for such activities, telling students "you just got to do it on your own because I don't have class time to spend doing that." She described how difficult it was to watch her students struggle, stating it was "sad to see the kids' faces, particularly those who are middle-to-low students who, when you're drilling all this stuff, you're looking at them and you know they can't remember it at all. And they're just, you know, sitting there knowing 'I'm going to fail this thing."'

Barry offered similar sentiments:

You know, we would all love to never have to lecture, but a textbook reading, and a worksheet on it has been followed up with your own introduction of the material. Especially, if anything, it's a kind of a scaffolding for those who didn't get the textbook because it's too hard... the problem is covering the entire modern world in one year, and being able to do that with appropriate depth.

The shift Marcus alighted upon, to "efficient methods, where I can cover more ground with lecture and notes," is most certainly having a corrosive effect on student learning of content, but also in terms of their development as citizens.

\section{Conclusions and Policy Implica- tions}

This study suggests several conclusions that have implications for standards and testing as they relate to social studies teaching. Ohio secondary social studies teachers appear to have a strong commitment to their subject as an area of study and high regard for its position in the curriculum. The findings revealed a group of social studies teachers who have a healthy respect for the standards and a commitment to citi- 
zenship preparation, however defined, in spite of primarily indicating in survey responses that the primary reason for teaching social studies is to "teach students an appreciation and awareness of their community, nation, and the world." Nonetheless, nearly all believe they are profoundly constrained by the presence of the high-stakes tests. Teacher perceptions of the present purposes of the social studies may serve to both advance and undermine the purposes of the standards. Although teachers convey a fairly clear understanding of the citizenship preparation purpose of social studies as stated in the OACS, planning for powerful teaching appears to be heavily marginalized (Vogler, 2005; Vogler \& Virtue, 2007). Teachers repeatedly offered examples of how time constraints and testing as the curricular focus derailed their plans for powerful pedagogy. This planning process does not align closely with the intent of the Ohio Academic Content Standards (OACS) or the performance expectations of the National Council for the Social Studies (NCSS, 1994). Given these collateral effects of testing, as well a surfeit of other well-documented pernicious consequences, we recommend that high-stakes testing be eliminated or severely modified (Johnson, Johnson, Farenga \& Ness, 2008; Jones, Jones, \& Hargrove, 2003).

One apparent consequence of these assessment policies is the abandonment of student-centered strategies that promise to promote the development of participatory citizens committed to social justice. Teachers who value student-centered methods are modifying what they consider to be best practice in order to address external demands, while active teaching appears to be relegated to elective courses whose content is not part of the high-stakes tested curriculum (Gerwin \& Visone, 2006). Generally, we found there is an insistent focus on breadth over depth. There are also concerns about the content validity of the test, given that the test includes content that used to be covered between March and June as well as content covered in U.S. Government. Finally, the OAT and OGT limit teacher professional autonomy by creating an unfavorable context for teachable moments, current events, and opportunities for student inquiry. Unfortunately, there does not seem to be a wide range of policy options in response to these noxious effects outside of following the status quo, a complete overhaul of how education operates within a new paradigm of corrective and restorative justice, or perhaps more narrowly, the complete elimination of high-stakes tests (Hursh, 2008; Johnson et al., 2008).

Given the omnipresence and powerful effects of state educational policy on teaching (ongoing challenges associated with state standards, high-stakes testing, and teacher preparation in a climate of educational change), the social studies field has a responsibility to continuously monitor and explore intended and unintended consequences of state testing for democratic citizenship education. The results of this study offer social studies teacher education programs and state policymakers a clearer sense of the nature of classroom transformation as well as an impetus for more effective preservice teacher education and inservice professional development for teachers. In the main, social studies teachers in Ohio face the daunting challenge of covering content while fostering active democratic citizenship.

Policy that engenders curriculum well aligned to the OACS could easily advance the purposes of civic competence. In general, teachers are familiar with and supportive of the standards themselves, incorporate the standards in their planning, and offer minor constructive criticisms about scope and sequence. They are concerned about the narrowing of the curriculum as a by-product of the state tests. These concerns are directed more toward the marshalling of the curriculum in service to the test and are not a complaint directed expressly at the standards per sé. Although the standards are typically viewed positively, in the context of testing, limited instructional time, and decreased curricular autonomy, they have a largely negative educational effect.

State and local policymakers need to revisit the unintended consequences of these exams and determine another way. Slated to take effect in 20142015, the Ohio legislature has proposed revisions to the process that require reducing the stakes of the test by substituting it with multiple end-of-course exams and adding a portfolio-based assessment (Ohio Department of Education, 2010). This is a shift in the right direction. The nature of these assessments, however, is as yet undetermined, but we would suggest a more authentic assessment that assesses students as citizens and focuses more on skills and dispositions. Alternatively, we could think of a new 
course design that breaks down disciplinary boundaries and uses enduring social, political, and economic problems as a curriculum bit. Then, currently isolated content could find connectivity to problems in which students engage with substantive inquiry. As it stands, in these situations, normally talented teachers are so constrained by the exit exam parameters that the optimal learning outcome becomes mastery of uncomplicated content knowledge, bereft of connective tissue and greater meaning (Misco, 2010). It is a case of policy in the way of practice, of interfering with and constraining rather than effectively assisting in true attainment of educational goals.

\section{References}

Barton, K. C., \& Levstik, L. E. (2004). Teaching history for the common good. Mahwah, NJ: Lawrence Erlbaum Associates, Publishers.

Cole, C., Palmer, R., \& Schwanz, D. (1997). Improving the mail return rates of SASS surveys: A review of the literature. Working Papers Series: Office of Educational Research and Improvement, National Center for Education Statistics. Washington, D.C.: United States Department of Education.

Dillman, D. A. (1991). The design and administration of mail surveys. Annual Review of Sociology, 17, 225-249.

Doppen, F., Misco, T., \& Patterson, N.C. (2008). The state of $\mathrm{K}-12$ social studies instruction in Ohio. Social Studies Research and Practice, 3(3), 1-25.

Firestone, W. A., Schorr, R. Y., \& Monfils, L. F. (2004). The ambiguity of teaching to the test: Standards, assessment, and educational reform. Mahwah, NJ: Erlbaum.

Fox, R., Crask, M. R., \& Kim, J. (1988). Mail survey response rate: A meta-analysis of selected techniques for inducing response. The Public Opinion Quarterly, 52(4), 467-491.

Gerwin, D., \& Visone, F. (2006). The freedom to teach: Contrasting history teaching in elective and state-tested course. Theory and Research in Social Education, 34(2), 2-25.

Glasser, B., \& Strauss, A. (1967). The discovery of grounded theory. Chicago: Adeline.

Glesne, C. (1999). Becoming qualitative researchers. New York: Longman.
Grant, S. G., \& Salinas, C. (2008). Assessment and accountability in the social studies. In L. S. Levstik \& C. A. Tyson (Eds.), Handbook of research in social studies education (pp. 219-236). New York, NY: Routledge.

Grant, S. G. (2001). An uncertain lever: Exploring the influence of state-level testing in New York State on teaching social studies. Teachers College Record, 103(3), 398-426.

Hammersley, M., \& Atkinson, P. (1995). Ethnography. New York: Routledge.

Heafner, T., Lipscomb, G. B., \& Rock, T. (2006). To test or not to test?: The role of testing in elementary social studies. A collaborative study conducted by NCPSSE and SCPSSE. Social Studies Research and Practice, 1(2), 145-164.

Hursh, D. W. (2008). High-stakes testing and the decline of teaching and learning: The real crisis in education. Lanham: Rowman \& Littlefield Publishers.

Johnson, D. D., Johnson, B., Farenga, S. J., \& Ness, D. (2008). Stop high-stakes testing: An appeal to America's conscience. Lanham: Rowman \& Littlefield Publishers.

Jones, M. G., Jones, B. D., \& Hargroves, T. (2003). The unintended consequences of high-stakes testing. Lanham, MD .: Rowman \& Littlefield.

LeCompte, M. D., \& Schensul, J. J. (1999a). Designing and conducting ethnographic research. Walnut Creek, CA: AltaMira.

LeCompte, M. D., \& Schensul, J. J. (1999b). Analyzing $\mathcal{E}$ interpreting ethnographic data. Walnut Creek, CA: AltaMira.

Leming, J. S., Ellinton, L., \& Schug, M. (2006). The state of social studies: A national random survey of elementary and middle school social studies teachers. Social Education, 70(5), 322-327.

Marker, P. (2001). Standards and high stakes testing: The dark side of a generation of political, economic and social neglect of public education. Theory and Research in Social Education, 29(2), 357-362.

Merriam, S. B. (2001). Qualitative research and case study applications in education. San Francisco, CA: Jossey-Bass.

Miles, M. B., \& Huberman, A. M. (1994). Qualitative data analysis. Thousand Oaks, CA: Sage. 
Misco, T. (2010). Remediation for another highstakes test: An up-close, personal look inside a remedial test preparation course for a social studies exit exam reveals mastery of simple contentbut at what cost? Kappa Delta Pi Record, 46(3), 121-126.

National Council for the Social Studies. (1994). Expectations of excellence: Curriculum standards for social studies. Silver Spring, MD: Author.

Ohio Department of Education. (2010). Social studies revised academic content standards (2010) and model curriculum development. Retrieved June 1, 2011 from

http://www.ode.state.oh.us/GD/Templates/Pages/O DE/ODEDetail.aspx?page $=3 \&$ Topic RelationID $=17$ 06\&ContentID $=76598$

Ohio Department of Education. (2002). Social studies academic content standards. Retrieved February 1, 2007 , from http://www.ode.state.oh.us/GD/Templates/Pages/O DE/ODEDetail.aspx? page $=3 \&$ Topic RelationID $=33$ $5 \&$ ContentID $=852 \&$ Content $=18582$

Pajares, M. F. (1992). Teachers' beliefs and educational research: Cleaning up a messy construct. Review of Educational Research, 62(3), 307-332.

Patton, M. Q. (1990). Qualitative evaluation and research methods. Newbury Park, CA: Sage.

Rock, T. C., Heafner, T., O'Connor, K., Passe, J., Oldendorf, S., Good, A., et al. (2006). One state closer to a national crisis: A report on elementary social studies education in North Carolina schools. Theory and Research in Social Education (34) $4,455-483$.

Segall, A. (2003). Teachers' perceptions of the impact of state-mandated standardized testing: The Michigan Educational Assessment Program (MEAP) as a case study of consequences. Theory and Research in Social Education, 31(3), 287-325.

Torney-Purta, J., Lehman, R., Oswald, H., \& Schulz, W. (2002). Citizenship and education in twentyeight countries. Amsterdam: International Association for the Evaluation of Education Achievement. Retrieved February 1, 2007, from: http://www.wam.umd.edu/ jtpurta/interreport.htm
VanFossen, P. J. (2005). "Reading and math take so much time...": An overview of social studies instruction in elementary classrooms in Indiana. Theory and Research in Social Education, 33(3), 376-403.

Vogler, K. E. (2005). Impact of a high school graduation examination on social studies teachers' instructional practices. Journal of Social Studies Research, 29(2), 19-33.

Vogler, K. E., \& Virtue, D. (2007). "Just the facts, Ma'am": Teaching social studies in the era of standards and high-stakes testing. The Social Studies, 98(2), 54-58.

Westheimer, J., \& Kahne, J. (2004). What kind of citizen? The politics of educating for democracy. American Educational Research Journal, 41(2), 237269.

Wright, R. J. (2009). Methods for improving test scores: The good, the bad, and the ugly. Kappa Delta Pi Record, 45(3), 116-121.

Yammarino, F. J., Skinner, S. J., \& Childers, T. L. (1991). Understanding mail survey response behavior: a meta-analysis. Public Opinion Quarterly, 55.

Yeager, E. A., \& Van Hover, S. (2006). Virginia vs. Florida: Two beginning teachers' perceptions of the influence of high-stakes testing on their instructional decision-making. Social Studies Research and Practice, 1(3), 340-358. 


\section{Appendix A}

Interview Questions:

Topic 1: Purposes of Social Studies Education

1. What are your reasons for teaching social studies?

2. In the survey you were asked to rank order content areas in terms of importance. Where did you rank it and why did you rank it this way?

3. From your perspective, what is the purpose of social studies education? How important is it to you?

4. To what extent do you feel these aims, goals, and objectives are realized in your classroom?

5. What factors help and/or prevent you from accomplishing these aims and goals? (if OAT/OGT is not mentioned, ask)

6. You had said that characteristics of a good citizen are Can you elaborate?

7. To what extent do you believe you are preparing students to be citizens? (Depending on answer, move on to the following)

8. Tell me more about your vision of citizenship education. OR, please elaborate on your response.

Topic 2: OACS/OAT/OGT $\rightarrow$ Autonomy, practice, etc.

9. How do you feel about/What is your perspective on the Ohio Academic Content Standards? Tell me about the ways in which you employ them in your teaching or what you teach outside of the standards.

10. Do you think your beliefs about the purposes of social studies education and citizenship education are compatible with the OACS?

11. How do the standards influence the way you teach?

12. How do the standards influence what you teach?

IJEPL is a joint publication of the Association for Supervision and Curriculum Development, the Faculty of Education at Simon Fraser University, and the College of Education and Human Development at George Mason University. By virtue of their appearance in this open access journal, articles are free to use, with proper attribution, in educational and other non-commercial settings 90 days after initial publication. Copyright for articles published in IJEPL is retained by the authors. More information is available on the IJEPL Web site: http://www.ijepl.org 